\title{
Implementasi Technology Acceptance Model terhadap Adopsi Teknologi Artificial Intelligence pada Startup Digital
}

\author{
Margo Purnomo*, Erna Maulina, Aulia Rizki Wicaksono, Muhamad Rizal \\ Program Doktor, Fakultas Ilmu Sosial dan Politik Universitas Padjajaran \\ Bandung, Indonesia \\ *purnomo@unpad.ac.id
}

\begin{abstract}
The purpose of this study is to describe and analyze the implementation of the technology acceptance model on the adoption of artificial intelligence technology in digital startups. By using simple random sampling, a sample of 109 out of 143 populations, which are startups in Greater Jakarta, was obtained. Based on an analysis using Structural Equation Modeling (SEM) analysis with the SmartPLS tool. The results show that the adoption of artificial intelligence in digital startups is influenced by attitudes, perceptions of convenience and perceptions of usefulness. Likewise, perceived convenience and perceived usefulness are significantly affected by external pressures.
\end{abstract}

Keywords: Adoption, Artificial Intelligence, Startups, Technology Acceptance Model

\section{PENDAHULUAN}

Perkembangan teknologi kecerdasan buatan (Artificial Intelligence) merupakan bagian dari kemajuan yang sangat pesat dari perkembangan Ilmu Pengetahuan Teknologi dan Seni (IPTEKS) di dunia. Cakupan dari teknologi Artificial Intelligence ini masih tergolong sangat luas sehingga pemanfaatannya juga beraneka ragam pada berbagai sektor industri (Hall \& Pesenti, 2017). Perkembangan teknologi Artificial Intelligence ini akan semakin terasa terutama bila diimplementasikan di dalam sektor bisnis maupun industri. Seperti yang dinyatakan Kumar dan Kalse bahwa penggunaan Artificial Intelligence dapat membantu dalam pengembangan bisnis dari perusahaan kecilmenengah hingga organisasi besar (Kumar \& Kalse, 2021)

Hal ini diperkuat dengan pernyataan dalam penelitian Maulina, dkk (2020) bahwa beberapa Startup terkemuka di Indonesia diketahui telah menerapkan teknologi
Artificial Intelligence untuk meningkatkan kualitas produk dan layanannya (Maulina, Purnomo, Wicaksono, \& Rizal, 2020) Di sinilah terlihat peran Artificial Intelligence sangat diperlukan. Artificial Intelligence dapat membantu memangkas waktu yang biasa digunakan untuk melakukan aktivitas pekerjaan yang seharusnya dapat dilakukan secara otomatis dengan menggunakan sistem komputer dan bantuan Artificial Intelligence (Metaxiotis, Ergazakis, \& Samouilidis, 2004); (Tsui, Garner, \& Staab, 2000). Banyak hal yang dapat dilakukan dengan penggunaan teknologi Artificial Intelligence ini, diantaranya adalah membantu sistem pengumpulan dan pengarsipan data, serta perintah-perintah sederhana lainnya. Hal tersebut yang membuat banyak perusahaan yang sangat optimis bahwa Artificial Intelligence nantinya suatu saat dapat meningkatkan performa perusahaan dan sekaligus kenaikan laba (Buck \& Morrow, 2018); (Lin, et al., 2017). Dengan kata lain, 
kemajuan pengembangan di bidang teknologi tergantung pada tingkat penerimaan teknologi Artificial Intelligence oleh user (perusahaan). Oleh karena itu muncul Theory of Reasoned Action (TRA) merupakan model referensi teoritis digunakan untuk memprediksi atau menjelaskan perilaku (Fisbein \& Ajzen, 1975). Selanjutnya berdasarkan model teoritis TRA, Davis (1989) mengembangkan model untuk mengeksplorasi hubungan antara sikap dan niat perilaku untuk mengadopsi teknologi yang disebut dengan Technology Acceptance Model (Davis, 1989). Technology Acceptance Model (TAM) mengasumsikan bahwa penentu utama niat perilaku mengadopsi teknologi tergantung pada keyakinan tentang kemudahan dalam menggunakan teknologi yang ada dan evaluasi subjektif tentang kegunaan teknologi itu sendiri (Bruner II \& Kumar, 2005); (Pavlou, Liang, \& Xue, 2007); (Previtali \& Bof, 2009); (Dennis, Merrilees, Hernandez, \& Jimenez, 2009); (Thomas \& Veloutsou, 2013).

Para peneliti TAM sebelumnya sedikit yang menggunakan sudut pandang user yaitu perusahaan Startups dalam meneliti faktorfaktor yang mempengaruhi intensi Startups dalam menggunakan teknologi Artificial Intelligence (Alhashmi, Salloum, \& Abdallah, 2019). Hal ini dikarenakan adopsi Artificial Intelligence merupakan sebuah terobosan teknologi yang tergolong baru bagi perusahaan. Penggunaan adopsi Artificial Intelligence sebagai subjek penelitian serta TAM untuk meneliti seberapa besar potensi perusahaan dalam menggunakan Artificial Intelligence yang menjadi masalah penelitian yang penting saat ini.

\section{Pengaruh Tekanan Eksternal terhadap Persepsi Kemudahan}

Davis (1989) menyatakan bahwa sebuah perusahaan merasa percaya jika suatu sistem teknologi informasi dapat berguna maka perusahaan tersebut akan menggunakannya (Davis, 1989). Sebaliknya jika sebuah perusahaan merasa percaya bahwa sistem teknologi informasi ini kurang berguna maka perusahaan tersebut tidak akan menggunakannya. Oleh karena itu, dengan tekanan tekanan eksternal yang kompetitif perusahaan harus menjadi mudah untuk menggunakan teknologi dapat memberikan manfaat bagi perusahaan. Pernyataan ini didukung dengan beberapa hasil penelitian lainnya yang menunjukkan adanya pengaruh tekanan eskternal terhadap persepsi kegunaan (Abdullah, Ward, \& Ahmed, 2016); (Waluyani, Subroto, \& Purnomosidhi, 2018). Berdasarkan penjelasan di atas, hipotesis pengaruh tekanan eksternal terhadap persepsi kemudahan dinyatakan sebagai berikut:

$\mathrm{H}_{1}$ : Tekanan eksternal berpengaruh signifikan terhadap Persepsi Kemudahan

\section{Pengaruh Tekanan Eksternal terhadap Persepsi Kegunaan}

Pada studi terdahulu terkait TAM bahwa persepsi kegunaan memiliki hubungan positif antara tekanan tekanan eksternal dan manfaat yang dirasakan. Tekanan eksternal dimaksud adalah karakteristik positif dari suatu sistem yang secara positif mempengaruhi persepsi kegunaan (Davis, 1989); (Venkatesh \& Davis, 2000). Pernyataan ini didukung dengan beberapa hasil penelitian lainnya yang menunjukkan adanya pengaruh tekanan eskternal terhadap persepsi kegunaan (Abdullah, Ward, \& Ahmed, 2016); (Wijaya \& Budiman, 2019). Sedangkan (Abou-Shouk, Lim, \& Megicks, 2016) menggunakan dimensi tekanan lingkungan sebagai variabel tekanan eksternal Berdasarkan penjelasan di atas, hipotesis tekanan eksternal berpengaruh terhadap persepsi kegunaan dinyatakan sebagai berikut:

$\mathrm{H}_{2}$ : Tekanan eksternal berpengaruh signifikan terhadap Persepsi Kegunaan

\section{Pengaruh Persepsi Kemudahan terhadap Persepsi Kegunaan}

Persepsi kegunaan dapat diartikan sebagai suatu tingkat keyakinan dari perusahaan bahwa dengan menggunakan suatu sistem teknologi informasi dapat memberikan manfaat dalam melaksanakan aktivitas dan meningkatkan kinerjanya (Davis, 1989). Sementara Persepsi kemudahan penggunaan merupakan tingkat 
keyakinan sebuah perusahaan bahwa penggunaan suatu sistem teknologi informasi tidak memerlukan usaha apapun (free of effort) dan mudah untuk dipahami (Davis, 1989). Adanya tingkat kemudahan dalam menggunakan sistem teknologi informasi akan meyakinkan perusahaan bahwa sistem tersebut memiliki kegunaan sehingga menimbulkan rasa nyaman bila menggunakan sistem teknologi informasi tersebut (Venkatesh \& Davis, 2000). Pernyataan ini didukung dengan beberapa hasil penelitian lainnya yang menunjukkan adanya pengaruh persepsi kemudahan terhadap persepsi kegunaan (Abdullah, Ward, \& Ahmed, 2016); (Raza, Umer, \& Shah, 2017); (Bogea \& Brito, 2018) (Sugandini \& Purwoko, 2018); (Deisti, Sarah, \& Putri, 2019); (Winarno \& Putra, 2020). Berdasarkan penjelasan di atas, hipotesis pengaruh persepsi kemudahan terhadap persepsi kegunaan dinyatakan sebagai berikut:

$\mathrm{H}_{3}$ : Persepsi kemudahaan berpengaruh signifikan terhadap Persepsi Kegunaan

\section{Pengaruh Persepsi Kemudahan terhadap} Sikap

Dalam kontek adopsi IT pada sebuah organisasi menunjukan bahwa persepsi kemudahan untuk mengapdopsi teknologi mempengaruhi nilai strategi yang dirasakan manfaatnya oleh top manager. Hal tersebut selaras dengan hasil penelitian lainnya yang menunjukkan adanya persepsi kemudahan terhadap pengaruh sikap (Langelo, 2013); (Abdullah, Ward, \& Ahmed, 2016); (Raza, Umer, \& Shah, 2017); (Sugandini \& Purwoko, 2018); (Deisti, Sarah, \& Putri, 2019); (Wijaya \& Budiman, 2019). Bedasarkan penjelasan di atas, hipotesis pengaruh persepsi kemudahan terhadap pengaruh sikap dinyatakan sebagai berikut:

$\mathrm{H}_{4}$ : Persepsi kemudahan berpengaruh signifikan terhadap sikap

\section{Pengaruh Persepsi Kegunaan Terhadap Sikap}

Menurut TAM, persepsi kegunaan diyakini sebagai penentu utama teknologi yang diikuti oleh persepsi kemudahan
(Igbaria \& Iivari, 1995). Baik persepsi kemudahan maupun persepsi kegunaan mempengaruhi sikap individu terhadap niat untuk memanfaatkan suatu teknologi dan dalam hal ini M-banking (Rauniar, Rawski, Yang, \& Johnson, 2014). Pernyataan ini didukung dengan beberapa hasil penelitian lainnya yang menunjukkan adanya pengaruh persepsi kegunaan terhadap sikap (Raza, Umer, \& Shah, 2017); (Deisti, Sarah, \& Putri, 2019); (Wijaya \& Budiman, 2019). Berdasarkan penjelasan di atas, hipotesis pengaruh persepsi kegunaan terhadap sikap dinyatakan sebagai berikut:

$\mathrm{H}_{5}$ : Persepsi kegunaan berpengaruh signifikan terhadap sikap

\section{Pengaruh Persepsi Kemudahan terhadap Adopsi}

Literatur terdahulu menunjukkan banyak faktor yang mempengaruhi adopsi AI oleh UKM. Beberapa diantaranya adalah dalam penelitian lain yang menyatakan bahwa persepsi kemudahan berpengaruh secara positif terhadap adopsi (Langelo, 2013);(Sugandini \& Purwoko, 2018) Berdasarkan penjelasan di atas, hipotesis pengaruh persepsi kemudahan terhadap adopsi dinyatakan sebagai berikut:

$\mathrm{H}_{6}$ : Persepsi kemudahan berpengaruh signifikan terhadap Adopsi

\section{Pengaruh Persepsi Kegunaan terhadap Adopsi}

David (1989) menyatakan bahwa persepsi kegunaan merupakan sejauh mana seorang percaya bahwa menggunakan suatu teknologi akan meningkatkan kinerjanya sehingga secara tidak langsung hal ini akan berdampak pada tingkat keinginan untuk mengadopsi teknologi (Davis, 1989). Hal yang sama juga ditemukan dari hasil penelitian yang dilakukan oleh peneliti lainnya (Abou-Shouk, Lim, \& Megicks, 2016); (Raza, Umer, \& Shah, 2017) yang menyatakan bahwa persepsi kegunaan memiliki pengaruh positif terhadap adopsi teknologi informasi. Berdasarkan penjelasan di atas, hipotesis pengaruh persepsi kegunaan terhadap adopsi dinyatakan sebagai berikut: 
$\mathrm{H}_{7}$ : Persepsi kegunaan berpengaruh signifikan terhadap Adopsi

\section{Pengaruh Sikap Terhadap Adopsi}

David (1989) menyatakan sikap terhadap pemanfaatan teknologi dalam TAM dikonsepsikan sebagai sikap terhadap penggunaan teknologi yang berupa penerimaan atau penolakan, sebagai dampak dari penggunaan teknologi tersebut dalam pekerjaannya (Davis, 1989). Untuk itu perlu sikap yang jelas yang berpengaruh terhadap adopsi dalam suatu teknologi. Pernyataan ini didukung dengan beberapa hasil penelitian lainnya yang menunjukkan adanya pengaruh sikap terhadap persepsi kegunaan (Raza, Umer, \& Shah, 2017); (Deisti, Sarah, \& Putri, 2019); (Wijaya \& Budiman, 2019). Bedasarkan penjelasan di atas, hipotesis pengaruh sikap terhadap adopsi dinyatakan sebagai berikut:

$\mathrm{H}_{8}$ : Sikap berpengaruh signifikan terhadap adopsi

Berdasarkan uraian dan hipotesis yang terbentuk, makakerangka konseptualdalam penelitian ini dapat dilihat pada Gambar 1 berikut ini

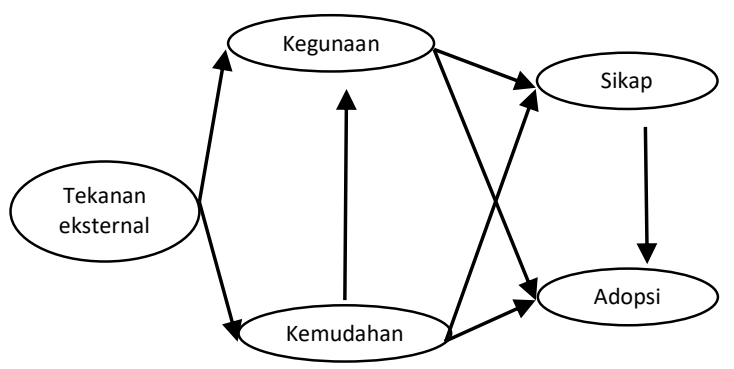

Gambar 1. Kerangka Konseptual Penelitian

\section{METODE}

Sesuai dengan tujuan penelitian yaitu untuk menganalisis Implementasi Technology Acceptance Model terhadap adopsi Teknologi Artificial Intelligence pada Startup Digital, maka analisis dilakukan dengan menyusun model menggunakan Structural Equation Modeling (SEM). Teknik pengambilan sampel dalam penelitian ini menggunakan teknik simple random sampling yang dilakukan secara acak tanpa memperhatikan strata yang ada pada populasi. Untuk menentukan berapa minimal sampel yang dibutuhkan maka dapat digunakan rumus Slovin yang diambil dari populasi yaitu perusahaan startup digital skala kecil merujuk pada data startup digital dengan status badan usaha bukan PT (Perseroan Terbatas) yang berlokasi di region Jabodetabek sebanyak 143. Dalam penelitian ini, peneliti menggunakan kelonggaran 5\% sehingga didapat jumlah sampel sebanyak 109 sampel.

Adapun variabel yang digunakan dalam penelitian ini dapat dilihat pada Tabel 1 berikut:

Tabel 1. Pengukuran Variabel

\begin{tabular}{|c|c|c|}
\hline Variabel & Indikator & Skala \\
\hline $\begin{array}{l}\text { Tekanan } \\
\text { Eksternal }\end{array}$ & $\begin{array}{l}\text { - } \text { tekanan dari } \\
\text { persaingan } \\
\text { - tekanan dari faktor } \\
\text { sosial } \\
\text { - Ketergantungan pada } \\
\text { perusahaan lain } \\
\text { - tekanan dari industri } \\
\text { - tekanan dari } \\
\text { pemerintah }\end{array}$ & Likert \\
\hline $\begin{array}{l}\text { Persepsi } \\
\text { Kemudahan } \\
\text { (sejauh mana } \\
\text { seseorang } \\
\text { percaya bahwa } \\
\text { menggunakan } \\
\text { teknologi akan } \\
\text { bebas dari usaha } \\
\text { (Davis, 1989). }\end{array}$ & $\begin{array}{l}\text { - } \text { mudah dipelajari } \\
\text { - dapat dikontrol } \\
\text { - jelas \& mudah } \\
\text { dipahami } \\
\text { - fleksibel } \\
\text { - mudah menjadi } \\
\text { terampil } \\
\text { - mudah digunakan }\end{array}$ & Likert \\
\hline $\begin{array}{l}\text { Persepsi } \\
\text { Kegunaan } \\
\text { (sebagai sejauh } \\
\text { mana seseorang } \\
\text { percaya bahwa } \\
\text { menggunakan } \\
\text { teknologi akan } \\
\text { meningkatkan } \\
\text { kinerjanya } \\
\text { (Davis, 1989). }\end{array}$ & $\begin{array}{l}\text { - bekerja lebih cepat } \\
\text { - kinerja pekerjaan } \\
\text { - meningkatkan } \\
\text { produktivitas dan } \\
\text { efektivitas } \\
\text { - membuat pekerjaan } \\
\text { lebih mudah dan } \\
\text { bermanfaat }\end{array}$ & Likert \\
\hline $\begin{array}{l}\text { Sikap } \\
\text { (sebagai evaluasi } \\
\text { pengguna atas } \\
\text { minat mereka } \\
\text { dalam } \\
\text { mengadopsi TI, } \\
\text { Mathieson, } \\
\text { 1991) }\end{array}$ & $\begin{array}{l}\text { - mendukung adopsi } \\
\text { teknologi } \\
\text { - kepercayaan } \\
\text { terhadap teknologi } \\
\text { - tanggapan positif } \\
\text { menggunakan } \\
\text { teknologi }\end{array}$ & Likert \\
\hline $\begin{array}{l}\text { Adopsi } \\
\text { (sebagai } \\
\text { penerimaan dan }\end{array}$ & $\begin{array}{l}\text { - penerimaan dan } \\
\text { penggunaan produk }\end{array}$ & Likert \\
\hline
\end{tabular}




\begin{tabular}{lcc}
\hline \multicolumn{1}{c}{ Variabel } & \multicolumn{1}{c}{ Indikator } & Skala \\
\hline $\begin{array}{l}\text { penggunaan } \\
\text { produk, layanan, }\end{array}$ & $\begin{array}{c}\text { penerimaan dan } \\
\text { penggunaan layanan }\end{array}$ \\
$\begin{array}{l}\text { atau ide secara } \\
\text { berkelanjutan, }\end{array}$ & $\begin{array}{c}\text { ide secara } \\
\text { baraghani, }\end{array}$ & \\
2007) & & \\
\hline
\end{tabular}

Sementara skala pengukuran yang digunakan adalah skala Likert dengan menggunakan 5 poin skala, yaitu $5=$ sangat setuju, $4=$ setuju, $3=$ ragu-ragu, $2=$ tidak setuju, $1=$ sangat tidak setuju.

Berdasarkan hipotesis yang telah dirumuskan sebelumnya, maka analisis data secara statistik dalam penelitian ini diukur dengan menggunakan software Smart-PLS (Partial Least Square) yang mulai dengan model pengukuran (outer model) yang digunakan untuk menguji validitas konstruksi dan reliabilitas instrument, model struktural (inner model) yang merupakan model struktural untuk memprediksi hubungan kausalitas antar variabel laten dan terakhir adalah pengujian hipotesis

Pengujian hipotesis ini dapat menggunakan perbandingan antara nilai dalam T-table dan nilai $T$-statistic, dimana jika nilai $T$-statistic lebih tinggi dibandingkan nilai $T$-table, berarti hipotesis dinyatakan terdukung atau diterima. Dikarenakan dalam penelitian ini menggunakan tingkat keyakinan 95 persen (alpha 95 persen) maka nilai T-table untuk hipotesis satu ekor (onetailed) adalah $>1,68023$. Kemudian analisis Partial Least Square (PLS) dalam penelitian ini dilakukan dengan menggunakan program Smart-PLS.

\section{HASIL DAN PEMBAHASAN Pengujian Model}

Untuk mengetahui apakah model dalam penelitian ini sudah tepat, maka terlebih dahulu dilakukan uji validitas konvergen dan diskriminan. Adapun hasil ujinya dapat dilihat Gambar 2

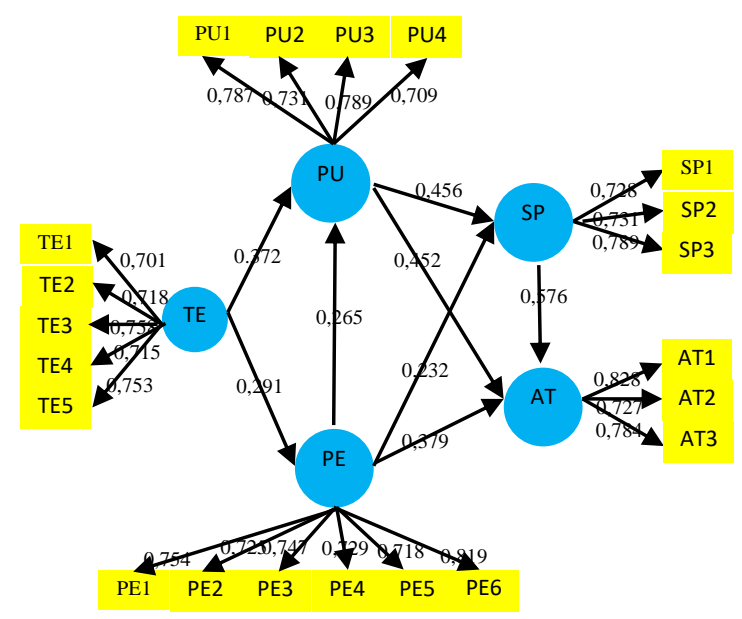

Gambar 2. Model Struktural

Dari Gambar 2 ini terlihat bahwa nilai loading factor dalam semua variabel berada diatas 0,6. Hal ini membuktikan bahwa setiap konstruk yang digunakan dalam penelitian ini mampu menjelaskan variabel yang ada. Setalah itu kemudian dilihat hasil uji validitas diskriminan. Uji ini menggunakan nilai cross loading. Suatu indikator dinyatakan memenuhi validitas diskriminan apabila nilai cross loading indikator pada variabelnya adalah yang terbesar dibandingkan pada variabel lainnya. Adapun nilai validitas diskriminan yang dimaksud dapat dilihat pada Tabel 2 berikut ini:

Tabel 2. Uji Validitas Diskriminan

\begin{tabular}{|c|c|c|c|c|c|}
\hline \multirow{2}{*}{ Indikator } & \multicolumn{5}{|c|}{ Variabel } \\
\hline & TE & $\mathrm{PE}$ & PU & SP & AT \\
\hline TE1 & 0,701 & & & & \\
\hline TE2 & 0,718 & & & & \\
\hline TE3 & 0,758 & & & & \\
\hline TE4 & 0,715 & & & & \\
\hline TE5 & 0,753 & & & & \\
\hline PE1 & & 0,754 & & & \\
\hline PE2 & & 0,725 & & & \\
\hline PE3 & & 0,747 & & & \\
\hline PE4 & & 0,729 & & & \\
\hline PE5 & & 0,718 & & & \\
\hline PE6 & & 0,819 & & & \\
\hline PU1 & & & 0,787 & & \\
\hline PU2 & & & 0,731 & & \\
\hline PU3 & & & 0,789 & & \\
\hline PU4 & & & 0,709 & & \\
\hline SP1 & & & & 0,728 & \\
\hline SP2 & & & & 0,731 & \\
\hline SP3 & & & & 0,789 & \\
\hline AT1 & & & & & 0,828 \\
\hline AT2 & & & & & 0,727 \\
\hline AT3 & & & & & 0,784 \\
\hline
\end{tabular}


Uji selanjutnya adalah uji reliabilitas dilakukan dengan menggunakan dua metode yaitu Cronbach's alpha dan Composite reliability. Tabel 3 dibawah ini menunjukan nilai yang dimaksud

Tabel 3. Nilai Reliabilitas

\begin{tabular}{lccc}
\hline \multicolumn{2}{c}{ Cronbach's } & $\begin{array}{l}\text { Composite } \\
\text { Reliability }\end{array}$ & AVE \\
\hline Tekanan Eksternal & 0,906 & 0,928 & 0,683 \\
Persepsi Kemudahan & 0,755 & 0,841 & 0,574 \\
Persepsi Kegunaan & 0,815 & 0,865 & 0,763 \\
Sikap & 0,759 & 0,826 & 0,625 \\
Adopsi & 0,852 & 0,896 & 0,732 \\
\hline
\end{tabular}

Tabel 3 di atas menunjukan bahwa nilai semua variabel dalam pengujian reliabilitas baik menggunakan Cronbach's Alpha ataupun Composite reliability nilainya $>0$, 70. Pengujian validitas dengan menggunakan AVE (Average Variance Extracted) nilainya $>0,50$. Oleh karena itu, dapat disimpulkan bahwa variabel-variabel yang diujikan valid dan juga reliabel, sehingga dapat dilanjutkan untuk menguji model struktural.

Setelah model yang diestimasi memenuhi kriteria validitas diskriminan dan reliabilitas, dan telah didapatkan model yang ideal sesuai dengan kerangka konseptual penelitian, selanjutnya dilakukan pengujian model struktural (inner model). Menilai inner model adalah melihat hubungan antar konstruk laten, dengan melihat hasil estimasi koefisien parameter path dan tingkat signifikansinya (Ghazali, 2018). Pengukuran model struktural dalam PLS dievaluasi dengan menggunakan $\mathrm{R}^{2}$. Pengukuran model struktural Nilai $\mathrm{R}^{2}$ digunakan untuk mengukur tingkat variasi perubahan variabel independen terhadap variabel dependen. Semakin tinggi nilai $\mathrm{R}^{2}$ berarti semakin baik model prediksi dari model penelitian Berikut nilai $\mathrm{R}^{2}$ pada konstruk yang disajikan pada Tabel 4 berikut ini menyajikan hasil penghitungan dari nilai $R$-Squares.

Tabel 4. Nilai $R$-Square

\begin{tabular}{ccr}
\hline Variabel & $\begin{array}{c}R \\
\text { Square }\end{array}$ & $\begin{array}{r}R \text { Square } \\
\text { Adjusted }\end{array}$ \\
\hline Adopsi AI & 0,833 & 0,826 \\
\hline
\end{tabular}

Berdasarkan tabel 4 di atas, nilai $\mathrm{R}^{2}$ pada variabel intensi adalah sebesar 0,833 . Hal tersebut menunjukan bahwa variabel faktor tekanan eksternal, persepsi kemudahan, persepsi kegunaan dan sikap memberikan nilai pengaruh sebesar $83,3 \%$ terhadap adopsi, sedangkan sisanya dijelaskan oleh variabel lain diluar penelitian ini. Sementara dasar pengujian hipotesis dalam penelitian ini adalah merujuk pada nilai yang terdapat pada output result for inner weight

Tabel 5. Hasil Pengujian Hipotesis

\begin{tabular}{lccc}
\hline Hubungan & $\begin{array}{c}\text { Original } \\
\text { Sample }(\mathrm{O})\end{array}$ & $\begin{array}{c}T \\
\text { Statistics }\end{array}$ & Keterangan \\
\hline $\begin{array}{l}\text { Tekanan eksternal } \\
\rightarrow \text { persepsi }\end{array}$ & & & \\
$\begin{array}{l}\text { kemudahan } \\
\text { Tekanan eksternal } \\
\rightarrow \text { persepsi }\end{array}$ & 0,291 & 5,204 & Diterima \\
$\begin{array}{l}\text { kegunaan } \\
\text { persepsi }\end{array}$ & 0,372 & 7,045 & Diterima \\
$\begin{array}{l}\text { kemudahan } \rightarrow \\
\text { persepsi kegunaan } \\
\text { persepsi }\end{array}$ & 0,265 & 5,148 & Diterima \\
$\begin{array}{l}\text { kemudahan } \rightarrow \\
\text { sikap }\end{array}$ & & & \\
persepsi kegunaan \\
$\rightarrow$ sikap & 0,232 & 4,845 & Diterima \\
$\begin{array}{l}\text { persepsi } \\
\text { kemudahan } \rightarrow\end{array}$ & 0,456 & 8,106 & Diterima \\
$\begin{array}{l}\text { adopsi } \\
\text { persepsi kegunaan } \\
\rightarrow \text { adopsi }\end{array}$ & 0,379 & 7,243 & Diterima \\
\begin{tabular}{l} 
Sikap $\rightarrow$ adopsi \\
\hline
\end{tabular} & 0,452 & 8,043 & Diterima \\
& 0,291 & 5,204 & Diterima \\
\hline
\end{tabular}

Berdasarkan hasil uji hipotesis, diketahui bahwa semua nilai $t$-statistic berada di atas 1,98. Hal ini menunjukkan bahwa semua variabel memiliki pengaruh signifikan. Untuk lebih jelasnya pengaruh antara variabel yang terjadi dapat dijelaskan sebagai berikut: Berdasarkan Tabel 5 dapat disimpulkan bahwa Tekanan eksternal berpengaruh positif signifikan terhadap persepsi kemudahan. Hasil ini menunjukkan bahwa tekanan eksternal cenderung akan meningkatkan persepsi kemudahan. Hasil penelitian ini mendukung penelitian yang dilakukan oleh peneliti-peneliti lain yang menyatakan adanya pengaruh tekanan eksternal terhadap persepsi kemudahan (Davis, 1989), (Abdullah, Ward, \& Ahmed, 2016) dan (Waluyani, Subroto, \& Purnomosidhi, 2018) 
Berdasarkan hasil uji hipotesis pada Tabel 5 dapat disimpulkan bahwa tekanan eksternal berpengaruh positif signifikan terhadap persepsi kegunaan. Hasil ini menunjukkan bahwa tekanan eksternal cenderung akan meningkatkan persepsi kegunaan. Hasil penelitian ini mendukung studi terdahulu terkait TAM bahwa terdapat hubungan positif antara tekanan eksternal dan manfaat yang dirasakan. Mengenali karakteristik positif dari suatu sistem secara positif mempengaruhi persepsi kegunaan (Davis, 1989); (Venkatesh \& Davis, 2000); (Abou-Shouk, Lim, \& Megicks, 2016); (Abdullah, Ward, \& Ahmed, 2016); (Wijaya \& Budiman, 2019).

Berdasarkan hasil uji hipotesis pada Tabel 5, dapat disimpulkan bahwa persepsi kemudahan berpengaruh signifikan terhadap persepsi kegunaan. Hasil penelitian ini menunjukkan bahwa persepsi kemudahan cenderung akan meningkatkan persepsi kegunaan. Hasil penelitian ini mendukung konsep yang yang menyatakan bahwa persepsi kegunaan ini juga dipengaruhi oleh adanya persepsi kemudahan penggunaan (Abou-Shouk, Lim, \& Megicks, 2016). Semakin mudah suatu sistem teknologi informasi digunakan maka sistem teknologi informasi tersebut dirasakan semakin bermanfaat. Hal ini juga didukung beberapa penelitian lainnya yang menunjukkan hasil yang sama (Abdullah, Ward, \& Ahmed, 2016); (Wijaya \& Budiman, 2019).

Berdasarkan hasil uji hipotesis pada Tabel 5, dapat disimpulkan bahwa persepsi kemudahan berpengaruh signifikan terhadap sikap. Hasil ini menunjukkan bahwa persepsi kemudahan cenderung akan meningkatkan sikap. Hasil penelitian ini mendukung beberapa hasil penelitian lainnya yang menunjukkan adanya pengaruh persepsi kemudahan terhadap sikap (Langelo, 2013); (Abdullah, Ward, \& Ahmed, 2016); (Raza, Umer, \& Shah, 2017); (Sugandini \& Purwoko, 2018); (Deisti, Sarah, \& Putri, 2019); (Wijaya \& Budiman, 2019)

Berdasarkan hasil uji hipotesis pada Tabel 5, dapat disimpulkan bahwa persepsi kegunaan berpengaruh signifikan terhadap sikap. Hasil ini menunjukkan bahwa Persepsi kegunaan cenderung kan meningkatkan sikap. Hasil penelitian ini mendukung pernyataan beberapa hasil penelitian lainnya yang menunjukkan adanya pengaruh persepsi kegunaan terhadap sikap (Raza, Umer, \& Shah, 2017); (Deisti, Sarah, \& Putri, 2019); (Wijaya \& Budiman, 2019).

Berdasarkan hasil uji hipotesis pada Tabel 5, dapat disimpulkan bahwa persepsi kemudahan berpengaruh signifikan terhadap adopsi. Hasil ini menunjukkan bahwa persepsi kemudahan cenderung akan meningkatkan adopsi. Hal tersebut selaras dengan peneliti yang yang menyatakan bahwa persepsi kemudahan berpengaruh secara positif terhadap adopsi (Langelo, 2013); (Sugandini \& Purwoko, 2018)

Berdasarkan hasil uji hipotesis pada Tabel 5, dapat disimpulkan bahwa persepsi kegunaan berpengaruh signifikan terhadap adopsi. Hasil ini menunjukkan bahwa persepsi kegunaan cenderung akan meningkatkan adopsi. Hasil penelitian ini mendukung penelitian yang dilakukan oleh (Davis, 1989) yang menyataan bahwa persepsi kegunaan yang diartikan sebagai tingkat di mana seseorang percaya bahwa menggunakan sistem tertentu dapat meningkatkan kinerjanya. Sekaligus bahwa jika perusahaan merasa percaya bahwa sistem berguna maka perusahaan tersebut akan menggunakannya. Sebaliknya, jika perusahaan merasa percaya bahwa sistem informasi tersebut kurang berguna maka perusahaan tersebut tidak akan menggunakannya. Begitu juga dengan penelitian yang menyatakan bahwa persepsi kegunaan memiliki pengaruh positif terhadap intensi dalam adopsi teknologi informasi (Abou-Shouk, Lim, \& Megicks, 2016) dan (Raza, Umer, \& Shah, 2017).

Berdasarkan hasil uji hipotesis pada Tabel 5, dapat disimpulkan bahwa Sikap berpengaruh positif signifikan terhadap adopsi. Hasil ini menunjukkan bahwa sikap cenderung akan meningkatkan adopsi. Hasil penelitian ini mendukung pernyataan hasil penelitian lainnya yang menunjukkan adanya pengaruh sikap terhadap adopsi (Raza, Umer, 
\& Shah, 2017); (Deisti, Sarah, \& Putri, 2019); (Wijaya \& Budiman, 2019).

\section{Kesimpulan}

Berdasarkan hasil serangkaian proses penelitian yang telah dilakukan, maka dapat disimpulkan bahwa adopsi artificial intelligence pada startup digital ini dipengaruhi oleh sikap, persepsi kemudahan dan persepsi kegunaan. Begitu juga persepsi kemudahan dan persepsi kegunaan dipengaruhi secara signifikan oleh tekanan eksternal.

Berdasarkan hasil dan kesimpulan yang ada, maka peningkatan adopsi artificial intelligence pada startup digital ini dapat dilakukan dengan mempertimbangkan sikap, tekanan eksternal, persepsi kegunaan dan kemudahan.

\section{DAFTAR PUSTAKA}

Abdullah, F., Ward, \& Ahmed, E. (2016). Investigating the influence of the most commonly used external variables of TAM on students' Perceived Ease of Use (PEOU) and Perceived Usefulness (PU) of eportfolios. Computers in Human Behavior 63 .

Abou-Shouk, M. A., Lim, W. M., \& Megicks, P. (2016). Using competing models to evaluate the role of environmental pressures in ecommerce adoption by small and medium sized travel agents in a developing country. Tourism Management, $52,327-339$.

Alhashmi, S. S., Salloum, S. A., \& Abdallah, S. (2019). Critical success factors for implementing artificial intelligence (AI) projects in Dubai government United Arab Emirates (UAE) health sector: Applying the extended technology acceptance model (TAM). International Conference on Advanced Intelegence System adn Informatics .

Bogea, F., \& Brito, E. Z. (2018). Determinants of social media adoption by large companies. Journal of technology management innovation, 13(1), 11-18.

Bruner II, G., \& Kumar, A. (2005). Explaining consumer acceptance of handheld Internet devices. Journal of Business Research, 58(5), 553-558.
Buck, B., \& Morrow, J. (2018). AI, performance management and engagement: keeping your best their best. Strategic HR Review.

Davis, F. D. (1989). Perceived usefulness, perceived ease of use, and user acceptance of information technology. MIS Quarterly, 319-340.

Deisti, A. F., Sarah, I. S., \& Putri, I. S. (2019). ETailing Consumer Adoption in The Indonesian Fashion Industry: The Role of Technology Acceptance Model. Jurnal Riset Bisnis dan Investasi, Vol. 5, No. 2 .

Dennis, C., Merrilees, B., Hernandez, B., \& Jimenez. (2009). Adoption vs acceptance of e-commerce: two different decisions. European Journal of Marketing.

Fisbein, M., \& Ajzen, I. (1975). Belief, attitude, intention and behavior: An introduction to theory and research. Massachusetts: Addison-Wiley Publishing Company.

Ghazali, I. (2018). Partial Least Squares Konsep, Teknik dan Aplikasi menggunakan Program SmartPLS 3.0 untuk Penelitian Empiris. Undip.

Hall, D. W., \& Pesenti, J. (2017). Growing the artificial intelligence industry in the UK. Report. UK: Department for Digital, Culture, Media \& Sport and Department for Business, Energy \& Industrial Strategy.

Igbaria, M., \& Iivari, J. (1995). 'The effects of self-efficacy on computer usage',. Omega,23(6), 587-605.

Kumar, A., \& Kalse, A. (2021). Usage and adoption of artificial intelligence in SMEs. Materials Today: Proceedings, https://doi.org/10.1016/j.matpr.2021.01. , 595.

Langelo, A. E. (2013). Perceived Usefulness, Perceived Ease Of Use, Perceived Risk Impact To Lecturers' Internet Banking Adoption. Jurnal EMBA, 1(4), 1571-1580.

Lin, C., Hsu, C., Lou, Y., Yeh, S., Lee, C., Su, S., et al. (2017). Artificial Intelligence Learning Semantics via External Resources for Classifying Diagnosis Codes in Discharge Notes. $J$ Med Internet Res;19(11):e380 .

Maulina, E., Purnomo, M., Wicaksono, A., \& Rizal, M. (2020). Analysis of the Use of Artificial Intelligence Technology on Digital Startups in Indonesia. International Journal of Advanced Science and Technology, 750-758.

Metaxiotis, K., Ergazakis, K., \& Samouilidis, E. (2004). Decision support through 
knowledge management: the role of the artificial intelligence. International Journal of Computer Applications in Technology, 19(2) , 101-106.

Pavlou, P., Liang, H., \& Xue, Y. (2007). Understanding and mitigating uncertainty in online exchange relationships: A principal-agent perspective. MIS QuarterlY , 105-136.

Previtali, P., \& Bof, F. (2009). E-government adoption in small Italian municipalities. International Journal of Public Sector Management .

Rauniar, R., Rawski, G., Yang, J., \& Johnson, B. (2014). Technology acceptance model (TAM) and social media usage: An empirical study on Facebook'. Journal of Enterprise Information Management, 27 , 6-30.

Raza, S. A., Umer, A., \& Shah, N. (2017). New determinants of ease of use and perceived usefulness for mobile banking adoption. Int. J. Electronic Customer Relationship Management, 11(1).

Sugandini, D., \& Purwoko. (2018). The role of uncertainty, perceived ease of use, and perceived usefulness towards the technology adoption. international journal of civil engineering and technology (IJCIET), 9(4) , 660-669.

Thomas, A. M., \& Veloutsou, C. (2013). Beyond technology acceptance: Brand relationships and online brand experience. Journal of Business Research - J BUS RES. 66. 10.1016/j.jbusres.2011.07.019.

Tsui, E., Garner, B., \& Staab, S. (2000). The role of artificial intelligence in knowledge management. Knowledge Based Systems, 13(5) , 235-239.

Venkatesh, V., \& Davis, F. D. (2000). A Theoretical Extension of the Technology Acceptance Model: Four Longitudinal Field Studies. Management Sciences. Vol. 46(2), 186-204.

Waluyani, R. C., Subroto, B., \& Purnomosidhi, B. (2018). Pengaruh Faktor Eksternal Technology Acceptance Model Terhadap Penerimaan Teknologi Online Travel Agent. Jurnal Economia, 14(2) .

Wijaya, T., \& Budiman, S. (2019). The Intention of Adopting Information Technology for SMES in Special Region of Yogyakarta. Jurnal Dinamika Manajemen, 10(2) , 205215.
Winarno, W. A., \& Putra, H. S. (2020). Technology acceptance model of the Indonesian government financial reporting information systems. International Journal of Public Sector Performance Management, 6(1), 68-84. 